8. Kuzmenko M. D. Veb-kvest «Skrynka tekstovykh zadach» [Text Quest Web Quest]. URL: http://ito.vspu.net/ENK/2011-2012/kompleks_new_magistru/rob_styd/13_14/Kuzmenko /index.html

9. Osadcha K. P., Osadchyi V. V. Orhanizatsijni prob̄lemy vprovadzhennia systemy upravlinnia kursamy u protsesi profesiinoi pidhotovky majbutnikh fakhivtsiv z informatsijnykh tekhnolohii [Organizational problems of implementation of the course management system in the process of professional training of future specialists in information technologies]. URL: http://2013. moodlemoot.in.ua/course/view. php

10. Sokol I. N. Klassifikatsia kvestov [Classification of quests]. Molodyj vchenyj. 2014. \#6 (09). P. 138-140.

11. Dodge B. Some Thoughts About Web Quests.1995-1997. URL: http://webquest.sdsu.edu/about_webquests.html

12. Erben T., Ban R., Castaneda $\bar{M}$. Teaching English Language Learners through Technology. Routledge, New York. 2009. P. 138.

УДК 54 (07):001.895

DOI 10.25128/2415-3605.21.1.4

\title{
ІГОР ВОЙТОВИЧ
}

ORCID ID: 0000-0003-2813-5225

igor_voitovich@ukr.net

доктор педагогічних наук, професор

Рівненський державний гуманітарний університет вул. Степана Бандери, 12, м. Рівне

\section{ОКСАНА ВОЙТОВИЧ}

ORCID ID: 0000-0003-3056-861X vojtovich_o@ukr.net

доктор педагогічних наук, доцент

Рівненський державний гуманітарний університет вул. Степана Бандери, 12, м. Рівне

ГАЛИНА МАРТИНЮК

ORCID ID: 0000-0001-6842-5601 galmart@ukr.net

кандидат хімічних наук, доцент

Рівненський державний гуманітарний університет вул. Степана Бандери, 12, м. Рівне

\section{ВИКОРИСТАННЯ ВІРТУАЛЬНИХ ЛАБОРАТОРІЙ В ПРОЦЕСІ ВИВЧЕННЯ ХІМІЧНИХ ДИСЦИПЛІН}

Розглянуто переваги і недоліки використання віртуальних лабораторій з хімії в освітньому прочесі підготовки майбутніх фахівців. Проаналізовано поняття «віртуальна лабораторія» та подано визначення віртуальної лабораторії з хімї як програмного середовища, що дозволяє з комп'ютерними моделями або безконтактно (дистанційно) з реальним обладнанням і реактивами формувати практичні уміння та навички шляхом проведення лабораторних дослідів, імітуючи послідовність дій дослідника в реальній лабораторії (або керуючи хімічними установками роботизованими засобами). Розглянуто наявні в інтернеті віртуальні лабораторії з хімії, які надають безкоштовний доступ до освітніх ресурсів та досліджено їх дидактичні і методичні можливості для підвищення рівня сформованості практичних умінь та навичок під час проведення хімічних дослідів. Встановлено, що використання віртуальної лабораторії з хімії сприяе формуванню практичних умінь при проведенні інтерактивних лабораторних занять з доповненням у реальних умовах; забезпечує індивідуальний темп оволодіння навичками хімічного експерименту; дає змогу досліджувати процеси, які потребують спечіальних умов; підвищує мотивацію до оволодіння новим матеріалом за рахунок роботи в віртуальному середовищі, щуо $\epsilon$ близьким та ичікавим для сучасного здобувача вищої освіти; забезпечує реалізачію самостійної підготовки до виконання дослідів в реальних лабораторних умовах. Проведене опитування здобувачів вищої освіти щодо ефективності впровадження віртуальних лабораторій в освітній прочес вивчення хімічних дисциплін дозволяе констатувати, щуо така форма організачї занять не повинна замінити традииійне виконання лабораторних робіт, а є лище їх доповненням. 
Ключові слова: віртуальна лабораторія, хімічні дисцииліни, здобувачі вищої освіти.

\title{
ИГОРЬ ВОЙТОВИЧ
}

доктор педагогических наук, профессор Ровненский государственный гуманитарный университет ул. Степана Бандеры, 12, г. Ровно

\author{
ОКСАНА ВОЙТОВИЧ \\ доктор педагогических наук, доцент \\ Ровненский государственный гуманитарный университет \\ ул. Степана Бандеры, 12, г. Ровно
}

\section{ГАЛИНА МАРТЫНЮК}

кандидат химических наук, доцент Ровненский государственный гуманитарный университет ул. Степана Бандеры, 12, г. Ровно

\section{ИСПОЛЬЗОВАНИЕ ВИРТУАЛЬНЫХ ЛАБОРАТОРИЙ В ПРОЦЕССЕ ИЗУЧЕНИЯ ХИМИЧЕСКИХ ДИСЦИПЛИН}

Рассмотрены преимущества и недостатки использования виртуальных лабораторий по химии в образовательном процессе подготовки будущиих специалистов. Проанализировано понятие «виртуальная лаборатория» и дано определение виртуальной лаборатории по химии как программной среды, что позволяет с компьютерными моделями или бесконтактно (дистанционно) с реальным оборудованием и реактивами формировать практические умения и навыки, путем проведения лабораторных опытов, имитируя последовательность действий исследователя в реальной лаборатории (или управляя химическими установками роботизированными средствами). Рассмотрены имеюшиеся 8 интернете виртуальные лаборатории по химии, которые предоставляют бесплатный доступ к образовательным ресурсам и исследованы их дидактические и методические возможности для повышения уровня сформированности практических умений и навыков при проведении химических опытов. Установлено, что использование виртуальной лаборатории по химии способствует формированию практических умений при проведении интерактивных лабораторных занятий с последующим закреплением в реальных условиях; обеспечивает индивидуальный темп овладения навыками химического эксперимента; позволяет исследовать процессы, которые требуют специальных условий; повымает мотивацию к изучению нового материала в прочессе работьл в виртуальной среде, что является близким и интересным для современного соискателя высшего образования; обеспечивает реализацию самостоятельной подготовки к выполнению опытов в реальных лабораторных условиях. Проведенный опрос соискателей высшего образования по эффективности внедрения виртуальных лабораторий в образовательный прочесс изучения химических дисциплин позволяет констатировать, что такая форма организации занятий не должна заменить традииионное выполнения лабораторных работ, а есть только их дополнением.

Ключевые слова: виртуальная лаборатория, химические дисциплины, соискатели высшего образования.

IHOR VOITOVYCH

Doctor of Pedagogical Sciences, Professor

Rivne State University of Humanities 12 Stepan Bandera Str., Rivne

OKSANA VOITOVYCH

Doctor of Pedagogical Sciences, Assistant Professor Rivne State University of Humanities 12 Stepan Bandera Str., Rivne 
Doctor of Philosophy, Assistant Professor Rivne State University of Humanities 12 Stepan Bandera Str., Rivne

\section{USE OF VIRTUAL LABORATORIES IN THE PROCESS OF TEACHING CHEMICAL DISCIPLINES}

The introduction of information and communication technologies in the educational process of teaching various disciplines is becoming increasingly important. Accordingly, the issue of application of these technologies in the teaching of chemical disciplines is relevant, namely the study of the possibility of using virtual laboratories in Chemistry as an interactive learning tool to improve the learning process and provide opportunities for professional and research skills. The purpose of the article is to study the possibilities of using virtual laboratories in the process of teaching chemical disciplines and to determine the opinion of students on the effectiveness of this type of activity. The following research methods are used in the article: theoretical analysis of scientific publications on the research problem; systematization and generalization of information; empirical - questionnaires and analysis of its results.

The article considers the advantages and disadvantages of using virtual Chemistry laboratories in the educational process. The article analyzes the concept of "virtual laboratory» and gives the definition of a virtual laboratory of Chemistry as a software environment that allows to form practical skills by conducting laboratory experiments, simulating the sequence of actions of the researcher in real laboratory (or managing chemical plants by robotic means) with use of computer models or contactless (remotely) with real equipment and reagents. We consider the virtual Chemistry laboratories available on the Internet, which provides free access to the educational resources and explores their didactic and methodological opportunities to increase the level of formation of practical skills and abilities during chemical experiments. It is established that the use of a virtual laboratory in Chemistry contributes to the formation of practical skills in conducting interactive laboratory classes with further consolidation in real conditions; provides an individual pace of mastering the skills of chemical experiment; allows students to explore processes that require special conditions; increases the motivation to master new material by working in a virtual environment that is familiar and interesting for the modern student; provides realization of its independent preparation for performance of experiments in real laboratory conditions. It is substantiated the use of virtual laboratories in Chemistry cannot substitute the traditional performance of laboratory work, but is only a supplementary form.

Keywords: virtual laboratory, chemical disciplines, students.

Кожен викладач закладу вищої освіти (ЗВО) прагне підготувати компетентного фахівця, який зможе реалізуватися в професійній діяльності. Але, на жаль, застаріла матеріальнотехнічна база цих закладів не дозволяє повноцінно сформувати у здобувачів вищої освіти практичні навички, зокрема навички хімічного експерименту. Оскільки суспільство переходить до епохи інформатизації усіх сфер життєдіяльності людини, то і сфера освіти потребує залучення інформаційно-комунікаційних технологій в освітній процес. Ці технології набувають все більшої популярності у вивченні різних дисциплін, в т. ч. природничих. У цьому контексті актуальним $є$ питання використання віртуальних лабораторій 3 хімії в освітньому процесі підготовки майбутніх фахівців педагогічних спеціальностей, як інтерактивного засобу навчання, що сприятиме підвищенню ефективності процесу навчання та забезпеченню більш широких можливостей для формування їхніх професійних і дослідницьких навичок.

Мета статті полягає у вивченні можливостей використання віртуальних лабораторій в процесі навчання хімічних дисциплін та з'ясуванні думки здобувачів вищої освіти щодо ефективності такого виду діяльності.

Віртуальна лабораторія є певним навчальним середовищем, яке дає змогу віртуально моделювати поведінку об'єктів дослідження і допомагає оволодіти новими знаннями та вміннями [7]. Вона повністю замінює лабораторну установку, тобто всім процесом займається комп’ютер, а дослідник лише має правильно налаштувати комп'ютерне обладнання [12].

Як зазначають фахівці, віртуальна лабораторія є певним програмним середовищем, в якому існує можливість дослідження об'єктів із заданою деталізацією щодо реальних процесів в рамках певної галузі знань [5]. Підтримуємо думку Ю. Ю. Гавронської та В. В. Оксенчук, що віртуальна лабораторія в навчання хімії - це комп’ютерна імітаційна хімічна лабораторія, що реалізує основну навчальну функцію, а саме: проведення хімічного експерименту [1]. 
Вважаємо, що віртуальна лабораторія з хімії є програмним середовищем, яке дозволяє 3 комп'ютерними моделями або безконтактно (дистанційно) 3 реальним обладнанням та реактивами формувати практичні уміння та навички шляхом проведення лабораторних дослідів, імітуючи послідовність дій дослідника в реальній лабораторії (або ж керуючи хімічними установками роботизованими засобами).

Нині в умовах ЗВО виконати всі досліди, передбачені навчальними програмами хімічних дисциплін, дуже складно як через відсутність окремих реактивів чи обладнання, так і через карантинні обмеження, тому використання програмних продуктів і вебдодатків представлених на інтернет-ресурсах дає можливість змоделювати та візуально продемонструвати певні хімічні досліди чи процеси.

Окремі дослідники відзначають деякі переваги використання віртуальної лабораторії в освітньому процесі підготовки фахівця, адже, на їх думку, порівняно 3 реальними лабораторними роботами вони дозволяють: змоделювати процеси, протікання яких неможливо реалізувати в лабораторних умовах; безпечно працювати 3 небезпечними речовинами чи приладами; зекономити на придбанні дорогих реактивів та обладнання; забезпечити самостійну організацію і проведення віртуального досліду здобувачами вищої освіти; використовувати віртуальну лабораторію як ефективний засіб отримання знань і вмінь у змішаному навчанні [8; 11$]$.

Відзначимо, що використання віртуальних лабораторій 3 хімії в освітньому процесі підготовки майбутніх фахівців дозволяє зекономити навчальний час і матеріальні ресурси лабораторій, адже інколи, в реальних умовах, хімічний експеримент може не вдатися і потрібно повторно виконати дослід або процес дуже повільний і його неможливо виконати в зазначений час. Ось тоді за допомогою інформаційно-комунікаційних технологій здобувачі вищої освіти можуть змоделювати і візуалізувати хімічний процес за значно коротший термін, маючи більше часу на аналіз результатів експерименту. Крім того, віртуальні лабораторії з хімії можна розглядати як засоби відпрацювання певних алгоритмів виконання хімічних дослідів, тобто вони $є$ віртуальними тренажерами.

Звичайно, що використання віртуальних лабораторій 3 хімії в освітньому процесі підготовки майбутнього фахівця має певні недоліки: неможливість працювати з реальним обладнанням і реактивами, що знижує рівень сприйняття інформації через органи чуття; обмеженість відображення реальної дійсності проходження хімічного експерименту; створення хибного бачення у здобувачів вищої освіти щодо легкості виконання лабораторних дослідів.

Тому, на нашу думку, віртуальні лабораторії з хімії не можуть повністю замінити проведення хімічних дослідів в реальних лабораторних умовах, але повинні використовуватись в умовах змішаного навчання в ЗВО. Сучасні віртуальні лабораторії сконструйовані так, що $є$ можливість підключитися до лабораторії навіть 3 мобільного пристрою, або ж встановити їх на смартфон.

Нами проаналізовано ряд публікацій та сервісів, що забезпечують доступ до віртуальних лабораторій 3 хімії. Серед них хочемо виділити ті, які мають безкоштовний доступ:

ChemCollective [4], що $є$ віртуальною лабораторією, яка дає змогу самостійно організувати роботу здобувача освіти шляхом моделювання та проведення досліду: зважування вихідних реагентів, вибір хімічного посуду і реактивів. Цікаво, що цей онлайнстимулятор хімічної лабораторії дозволяє здобувачам вищої освіти вибирати реагенти і маніпулювати ними, як у реальній лабораторії, візуалізуючи складні хімічні процеси. Зазначимо, що змістове наповнення даного ресурсу дуже обмежене і дозволяє лише поставити досліди $з$ деяких тем неорганічної, фізичної та аналітичної хімії (рис. 1). Ресурс містить також тести до представлених тем.

Ресурс англомовний, проте використання системи автоматизованого перекладу в браузері значно спрощує роботу. 
за допомогою проекту Віртуальної лабораторії та провести експеримент для визначення концентрації невідомого розчину $\mathrm{HCl}$ до чотирьох значущих цифр. Концентрації $\mathrm{HCl}$ та $\mathrm{NaOH}$ складають 0, IM та IM відповідно. Надаеться тверда КГП. Будь ласка, заповніть форму

зворотного зв'язку нижче, коли закінчите експеримент.

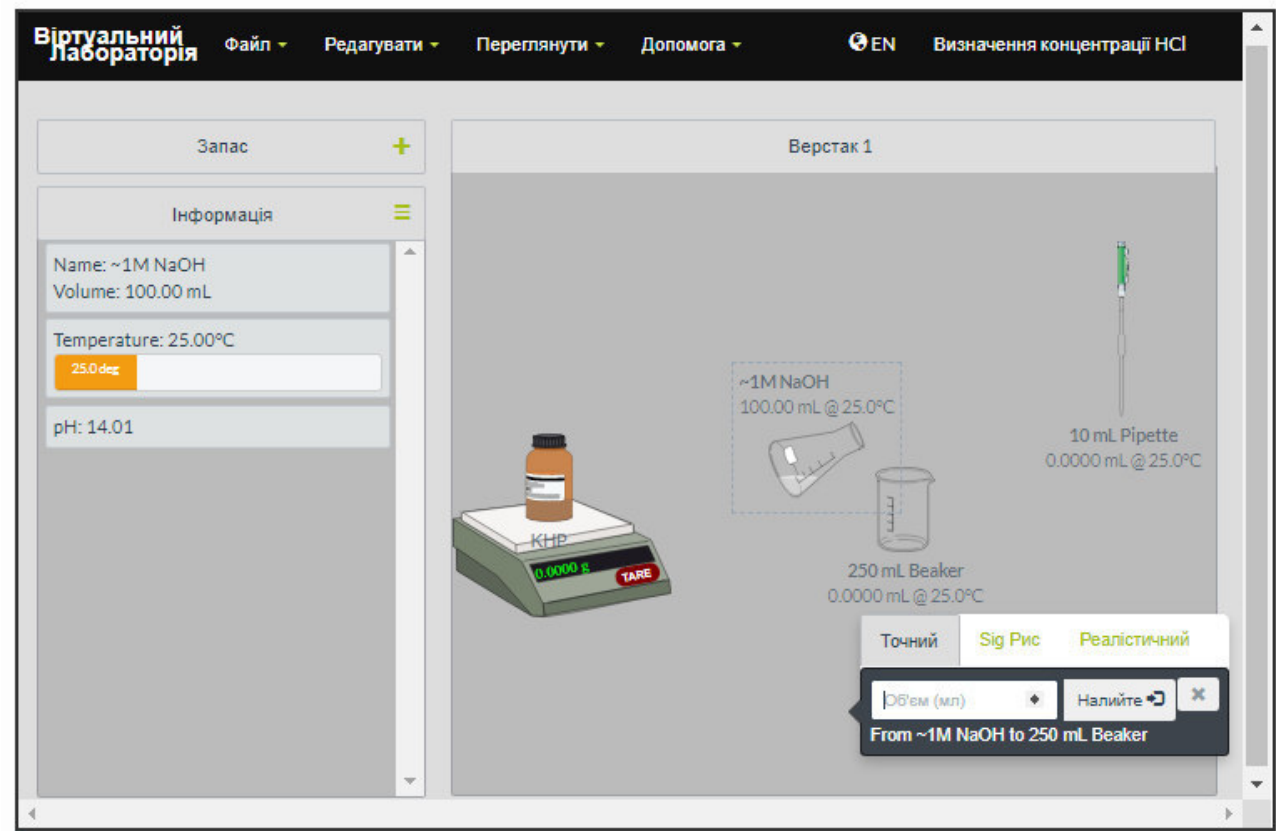

Бүдь ласка, введіть свою відповідь у форму нижче, використовуючи 4 значущі цифри для концентрації

Яка концентрація невідомого розчину $\mathrm{HCl}$ ? M.

Рис. 1. Виконання лабораторної роботи «Визначення роектів иії розчину $\mathrm{HCl}$ за допомогою $\mathrm{NaOH}$ та твердого гідрофталату калію КНР» у віртуальній лабораторіï ChemCollective [http://chemcollective.org/activities/autograded/128].

Phet Interactive Simulations $€$ програмою для моделювання певних дослідів, яка розроблена University of Colorado [3]. Вона має зручний інтуїтивно зрозумілий англомовний інтерфейс і нескладна в управлінні, реалізує моделювання певних процесів. Наприклад, модуль «Побудова атома» передбачає самостійне моделювання атома вибраного елемента, поступове конструювання атома 3 послідовним додаванням протонів, нейтронів, електронів (рис. 2). Таке інтерактивне моделювання $є$ засобом вивчення і розуміння будови атомів хімічних елементів та їх властивостей.
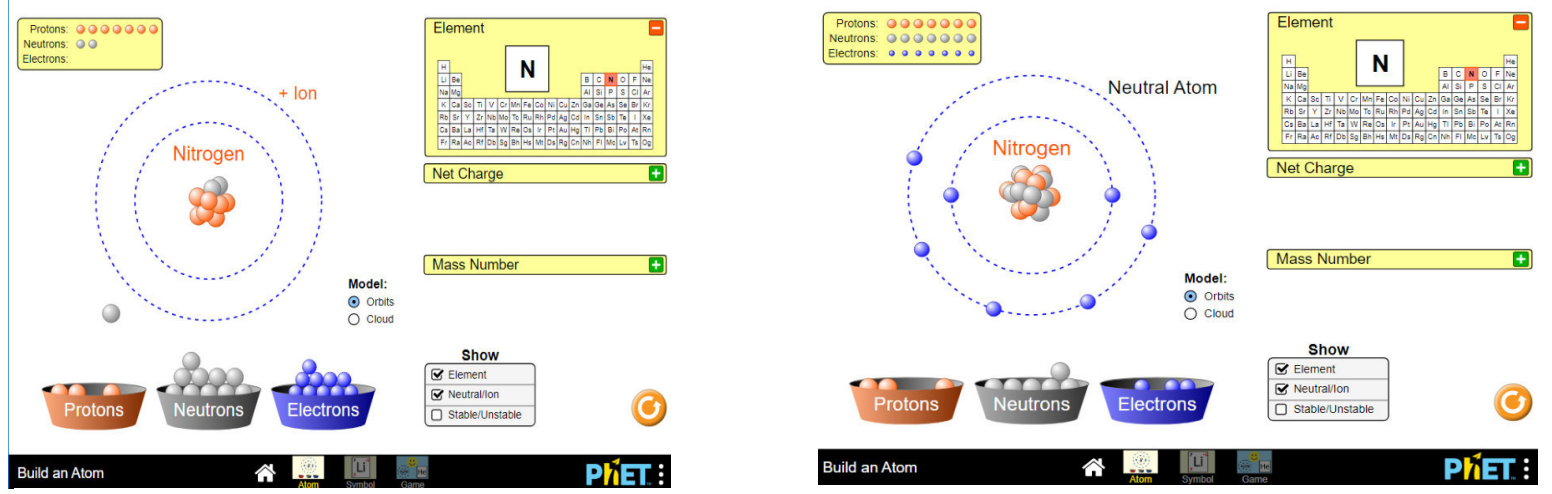

Рис. 2. Вікна для роботи в модулі «Побудова атома» [https://phet.colorado.edu/sims/html/buildan-atom/latest/build-an-atom_en.html].

Ряд дослідів можна провести віртуально у комплексній лабораторії Гарвардського університету [6], яка надає адаптивну систему вебвправ і генерує задачі для здобувачів освіти, спираючись на їх навички та показники (рис. 3). 


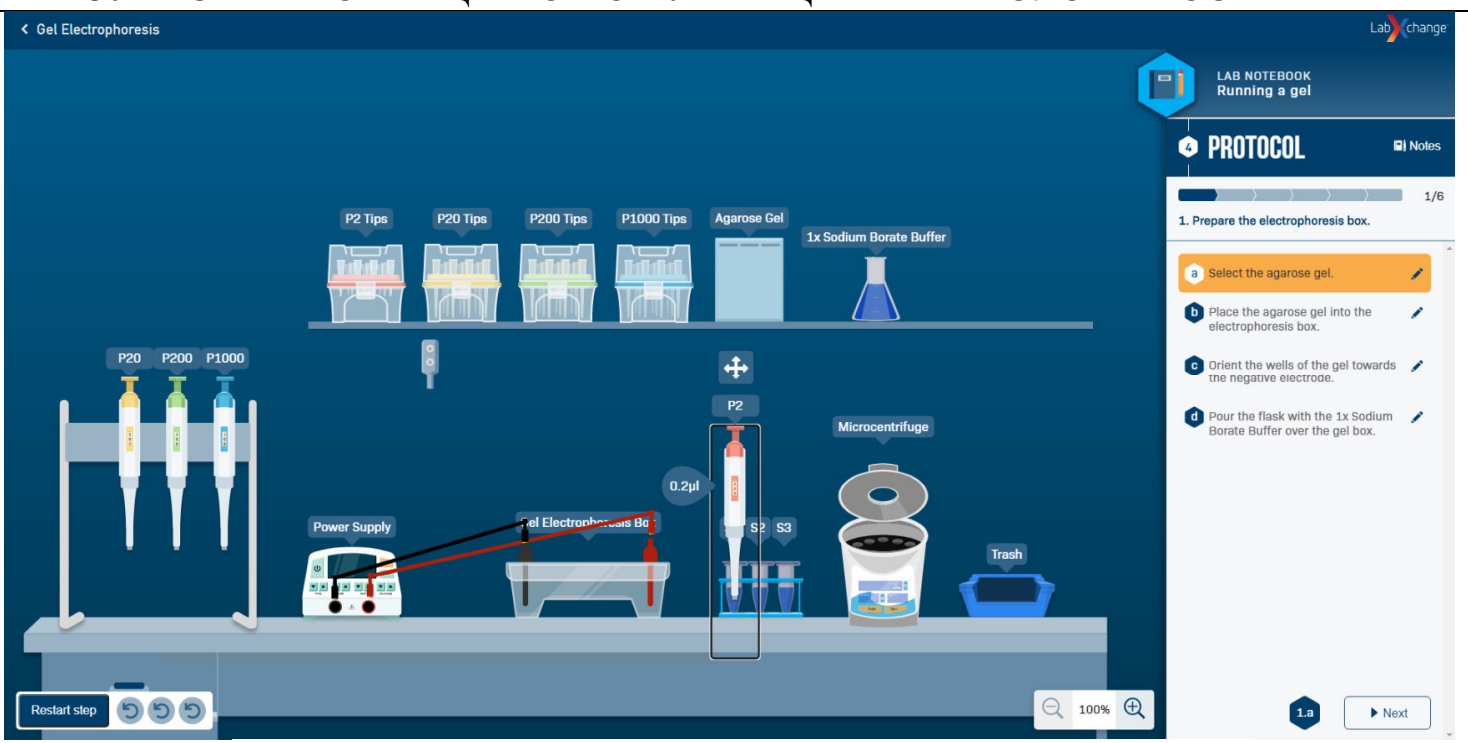

Рис. 3. Виконання лабораторної роботи «Гель електрофорез»

[https://www.labxchange.org/library/items/lb:LabXchange:9548bee3:lx_ simulation:1.

Ще одним корисним онлайн сервісом $\epsilon$ Wolfram.com, за допомогою якого можна переглянути ряд моделей [4] (рис. 4).

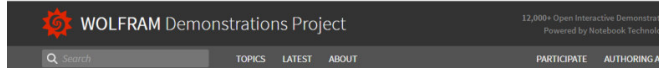

Alkanes $=$ serז

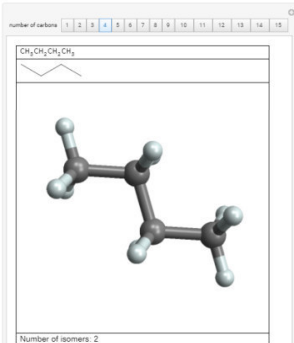

a

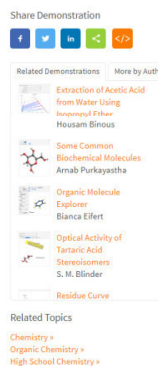

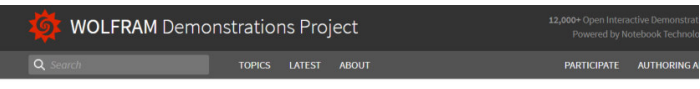

Build Your Own Atoms $\div$ BEAA

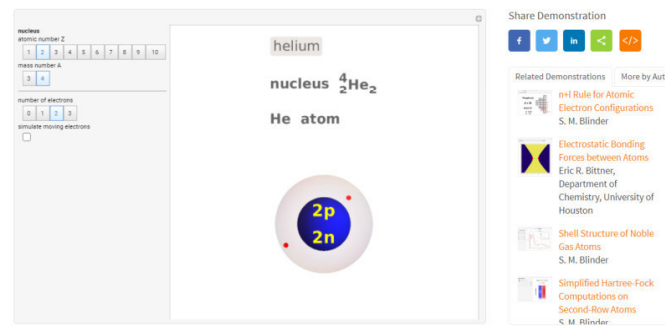

6

Рис. 4. Віртуальна модель «Алкани» (a) [https://demonstrations.wolfram.com/Alkanes/] і віртуальна модель «Побудувати атом» (б) [https://demonstrations.wolfram.com/BuildYourOwnAtoms/].

Доречно, щоб здобувачі вищої освіти були підготовлені до моделювання хімічних процесів у віртуальній лабораторії, а для цього вони повинні опрацювати теоретичний матеріал, ознайомитися з умовами проведення хімічних дослідів, необхідними матеріалами та реактивами. Наразі на інтернет-ресурсах $\epsilon$ всі можливості для самостійного навчання, наприклад, на безкоштовному хостингу сайтів від Google (Google Sites) створено роект «Хімія. Електронний підручник» [10], розроблений I. А. Гурняк. Звичайно, що цей роект не $\epsilon$ віртуальною лабораторією, оскільки лише регламентує пасивне спостереження за хімічним дослідом шляхом перегляду відеоматеріалів із записами експериментів на YouTube.

Ми рекомендували здобувачам вищої освіти спеціальностей «Середня освіта (Географія)», «Середня освіта (Біологія та здоров’я людини)», «Середня освіта (Природничі науки)» та «Екологія» використовувати цей електронний підручник як інтернет-ресурс для актуалізації хімічних знань, отриманих ними в закладі загальної середньої освіти. Також майбутніми фахівцями спеціальності «Середня освіта (Природничі науки)» цей ресурс може бути використаний як допоміжний засіб при підготовці до проведення уроків 3 хімії під час проходження практики і власне подальшої професійної діяльності й слугувати прикладом для розроблення власних освітніх ресурсів. 


\section{СУЧАСНІ ІНФОРМАЦІЙНО-КОМУНІКАЦІЙНІ ТЕХНОЛОГІЇ В ОСВІТІ}

Варто вказати, що змістове наповнення сайту дуже об'ємне. В підручнику подано чотири розділи: «Теорія», «Задачі», «Практикум», «Проєкти» (рис. 5).

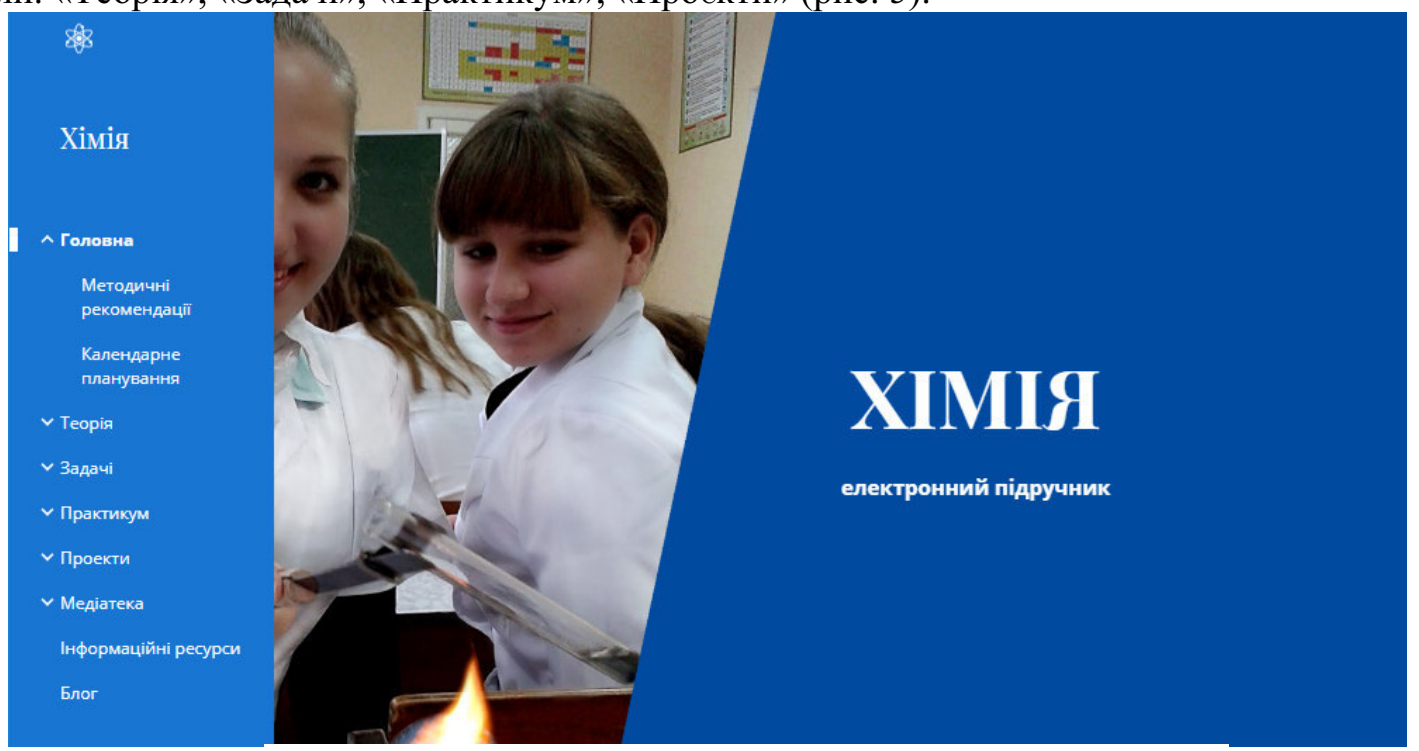

Рис. 5. Головна сторінка електронного підручника «Хімія» [https://sites.google.com/view/allhemi/].

Аналіз представленого матеріалу дозволяє стверджувати, що електронний підручник складений відповідно до навчальної програми «Хімія 10-11 класи. Рівень стандарту» [9]. Теоретичний матеріал подано коротко та лаконічно, хімічні властивості доповненні відеоматеріалами 3 YouTube, які сприяють візуалізації реакцій. У розділі «Задачі» подано приклади розв'язування різних типів хімічних задач і додаткові задачі для самостійного опрацювання. В розділі «Практикум» визначено певний перелік лабораторних робіт, які містять опис досліду та його візуалізацію за допомогою роликів з YouTube, завданням здобувачів освіти $є$ написання рівнянь реакцій. До кожної лабораторної роботи розроблено тести. У розділі «Проєкти» подано перелік тем і приклади виконаних роектів.

Звичайно, що має бути комплексний підхід до вибору моделі організації вивчення хімії у ЗВО, яка забезпечуватиме i оволодіння теоретичними хімічними знаннями, i розуміння хімічних процесів, i закріплення отриманих знань, і формування хімічної компетентності. Тому навчально-методичне забезпечення хімічних дисциплін повинно включати робочу програму дисципліни, підручники, методичні рекомендації, тестові завдання, електронні посібники, віртуальні лабораторії тощо.

Щоб оцінити ефективність впровадження віртуальних лабораторій в освітній процес підготовки майбутніх фахівців, нами було проведено опитування серед здобувачів вищої освіти для 3'ясування їхньої думки щодо такої форми виконання лабораторного практикуму. Здійснювалося опитування тих, хто мав досвід аудиторного виконання лабораторних робіт 3 хімії та використання віртуальних лабораторій в умовах карантинних обмежень.

Табличя 1

Результати опитування здобувачів вищої освіти

\begin{tabular}{|c|c|c|c|c|}
\hline $\begin{array}{c}\text { Хабораторного практикуму з } \\
\text { хімічних дисциплін } \\
\text { експеримент }\end{array}$ & $\begin{array}{c}\text { Кількість } \\
\text { здобува } \\
\text { чів вищої } \\
\text { освіти, } \\
\text { у \% }\end{array}$ & $\begin{array}{c}\text { Віртуальний } \\
\text { експеримент }\end{array}$ & $\begin{array}{c}\text { Кількість } \\
\text { здобувачів } \\
\text { вищої освіти, } \\
\text { у \% }\end{array}$ \\
\hline 1 & 2 & 3 & 4 & 5 \\
\hline $\begin{array}{l}\text { Теоретичні відомості } \\
\text { лабораторної роботи }\end{array}$ & до друкований формат & 15 & $\begin{array}{c}\text { електронний } \\
\text { формат }\end{array}$ & 85 \\
\hline $\begin{array}{l}\text { Вивчення інструкції } \\
\text { приладів та обладнання }\end{array}$ & додрукований формат & 22 & $\begin{array}{c}\text { електронний } \\
\text { формат }\end{array}$ & 78 \\
\hline
\end{tabular}


СУЧАСНІ ІНФОРМАЦІЙНО-КОМУНІКАЦІЙНІ ТЕХНОЛОГІЇ В ОСВІТІ

\begin{tabular}{|c|c|c|c|c|}
\hline 1 & 2 & 3 & 4 & 5 \\
\hline Проведення досліду: & & & & \\
\hline - можливість повторення & одноразово & 37 & $\begin{array}{l}\text { багато- } \\
\text { разово }\end{array}$ & 63 \\
\hline - небезпека для здоров’я & наявна & 48 & відсутня & 52 \\
\hline $\begin{array}{l}\text { - інтерес до виконання } \\
\text { хімічного досліду }\end{array}$ & & 86 & & 14 \\
\hline $\begin{array}{l}\text { Запис рівнянь } \\
\text { реакцій }\end{array}$ & $\begin{array}{c}\text { самостійний запис } \\
\text { та урівнювання }\end{array}$ & 45 & конструктор & 55 \\
\hline Звіт про виконану роботу & рукопис & 34 & електронний & 66 \\
\hline Форма роботи & групова & 64 & індивідуальна & 36 \\
\hline Оцінювання & & & & \\
\hline - форма & групове & 58 & індивідуальне & 42 \\
\hline - вид & усне, письмове & 46 & тестування & 54 \\
\hline
\end{tabular}

Установлено, що здобувачі вищої освіти, загалом підтримуючи віртуальну форму проведення хімічного експерименту (63\% відзначають перевагу багаторазового виконання дослідів у віртуальній лабораторії, а $52 \%$ - іiі безпечність для здоров'я), прагнуть виконувати реальні лабораторні роботи з використанням хімічних речовин та обладнання. 3 цього робимо висновок, що змішана форма навчання $\epsilon$ найбільш прийнятною в сучасних умовах, навіть без карантинних обмежень. Для цього нами розроблено електронні матеріали для підготовки до лабораторних робіт (теоретичні відомості, інструкції з техніки безпеки, інструкції для роботи 3 обладнанням та реактивами, хід роботи), тестові завдання для контролю та самоконтролю і можливість здавати електронні звіти про виконання роботи.

Вважаємо, що використання віртуальних лабораторій з хімії у ЗВО є невід'ємною складовою організації освітнього процесу, особливо в умовах впровадження змішаного навчання, що сприяє формуванню практичних умінь при проведенні інтерактивних лабораторних занять з доповненням у реальних умовах; забезпечує індивідуальний темп до оволодіння навичками хімічного експерименту; дозволяє досліджувати процеси, які потребують спеціальних умов; підвищує мотивацію до оволодіння новим матеріалом за рахунок роботи в віртуальному середовищі, що $є$ близьким для сучасного здобувача вищої освіти; забезпечує реалізацію самостійної підготовки до виконання дослідів в реальних лабораторних умовах.

Однак використання віртуальних лабораторій 3 хімії не може замітити традиційне виконання лабораторних робіт, а $є$ лише доповненням, що дозволяє навчатися здобувачам вищої освіти, які не змогли бути присутніми на конкретних заняттях; забезпечує закріплення навиків виконання хімічних дослідів; дозволяє розширити межі виконання лабораторних дослідів поза навчальною програмою; створює можливості для виконання лабораторних дослідів в умовах, коли немає можливості вийти 3 дому (наприклад, через карантинні обмеження) і запроваджено дистанційне навчання.

\section{ЛІТЕРАТУРА}

1. Гавронская Ю.Ю., Оксенчук В. В. Виртуальные лаборатории и виртуальный эксперимент в обучении химии.

URL:

https://lib.herzen.spb.ru/media/magazines/contents/1/178/gavronskaya_178_178_183.pdf (дата звернення 28.01. 2021).

2. Демонстраційний проєкт Wolfram: вебсайт. URL: https://demonstrations.wolfram.com/?source=footer (дата звернення 03.02. 2021).

3. Інтерактивні моделювання для науки та математики університету Колорадо: вебсайт. URL: https://phet.colorado.edu/ (дата звернення 25.01. 2021).

4. Інтернет-ресурси для викладання та вивчення хімії ChemCollective: вебсайт. URL: http://chemcollective.org/home (дата звернення 25.12. 2020).

5. Козловский Е. О., Кравцов Г. М. Виртуальная лаборатория в структуре системы дистанционного обучения. Информационные технологии в образовании. 2011. № 10 . URL: file:///C:/Users/Win10/Downloads/itvo_2011_10_15.pdf (дата звернення 27.01. 2021). 


\section{СУЧАСНІ ІНФОРМАЦІЙНО-КОМУНІКАЦІЙНІ ТЕХНОЛОГІЇ В ОСВІТІ}

6. Лабораторія факультету мистецтв та науки Гарвардського університету Labxchange: вебсайт. URL: https://www.labxchange.org (дата звернення 03.02. 2021).

7. Семеніхіна О. В., Шамоня В. Г. Віртуальні лабораторії як інструмент навчальної та наукової діяльності. Педагогічні науки: теорія, історія, інновачійні технології. Суми: Вид-во СумДПУ ім. А. С. Макаренка, 2011. № 1 (11). С. 341-346.

8. Трухин А. В. Об использовании виртуальных лабораторий в образовании. Открытое и дистанционное образование. 2002. № 4 (8). C. 70-72. URL: https://ido.tsu.ru/files/pub2002/4(8)309Truhin_A._(TUSUR).pdf (дата звернення 27.01. 2021).

9. Хімія 10-11 класи. Рівень стандарту. Навчальна програма для закладів загальної середньої освіти. Затверджено Міністерством освіти і науки України. Наказ № 1407 від 23.10.2017 p. URL: https://mon.gov.ua/ua/osvita/zagalna-serednya-osvita/navchalni-programi/navchalni-programi-dlya-1011-klasiv (дата звернення 26.01. 2021).

10. Хімія. Електронний підручник: вебсайт. URL: https://sites.google.com/view/allhemi/ (дата звернення 25.12. 2020).

11. Юрченко А. А. Виртуальные лаборатории в учебной физической среде. Інформаційні технології в професійній діяльності. 2016. № 10. URL: http://repository.sspu.sumy.ua/handle/123456789/979 (дата звернення 27.01. 2021).

12. Юрченко А. О., Хворостіна Ю. В. Віртуальна лабораторія як складова сучасного експерименту. Науковий вісник Ужгородського університету. Серія: «Педагогіка. Соиіальна робота». 2016. Вип. 2 (39). C. 281-283.

\section{REFERENCES}

1. Gavronskaya Yu. Yu., Oksenchuk V. V. Virtualnyje laboratorii i virtualnyj eksperyment v obuchenii himii. [Virtual laboratories and virtual experiment in teaching chemistry] URL: https://lib.herzen.spb.ru/media/magazines/contents/1/178/gavronskaya_178_178_183.pdf (data zvernennia 28.01. 2021).

2. Demonstracijnyj proekt Wolfram [Wolfram demonstration project]: veb-sajt. URL: https://demonstrations. wolfram.com/? source=footer (data zvernennia 03.02. 2021).

3. Interaktyvni modelyuvannya dlya nauky ta matematyky universytetu Kolorado [Interactive Simulations for Science and Mathematics, University of Colorado]: veb-sajt. URL: https://phet.colorado.edu/ (data zvernennia 25.01.2021).

4. Internet-resursy dlya vykladannya ta vyvchennya himiyi ChemCollective [Online resources for teaching and studying chemistry ChemCollective]: veb-sajt. URL: http://chemcollective.org/home (data zvernennia 25.12. 2020).

5. Kozlovskyj E. O., Kravczov G. M. Vyrtualnaia laboratoria v strukture systemy distancyonnogo obuchennia [Virtual laboratory in the structure of the distance learning system]. Informacyonnyie tehnologiyi v obrazovaniyi. 2011. № 10. URL: file:///C:/Users/Win10/Downloads/itvo_2011_10_15.pdf (data zvernennia 27.01. 2021).

6. Laboratoria fakultetu mystetstv ta nauky Garvardskogo universytetu Labxchange [Laboratory of the Faculty of Arts and Sciences of Harvard University Labxchange]: veb-sajt. URL: https://www.labxchange.org (data zvernennia 03.02. 2021).

7. Semenihina O. V., Shamonya V. G. Virtuani laboratorii yak instrument navchalnoi ta naukovoi dialnosti [Virtual laboratories as a tool for educational and scientific activities]. Pedagogichni nauky: teoria, istoria, innovacijni tehnologii. Sumy: Vyd-vo SumDPU im. A. S. Makarenka, 2011. № 1 (11). S. 341-346.

8. Truxyn A.V. Ob ispolzovanii virtualnykh laboratoryj $\mathrm{v}$ obrazovanii [There virtual laboratories using in education]. Otkrytoje distancyonnoje obrazovanyje. 2002. № 4 (8). S. 70-72. URL: https://ido.tsu.ru/files/pub2002/4(8)309Truhin_A._(TUSUR).pdf (data zvernennia 27.01. 2021).

9. Himia 10-11 klasy. Riven standartu. Navchalna programa dla zakladiv zagalnoi serednoi osvity [Chemistry 10-11 classes. Standard level. Curriculum for general secondary education institutions]. Zatverdzheno Ministerstvom osvity i nauky Ukrayiny. Nakaz № 1407 vid 23.10.2017 r. URL: https://mon.gov.ua/ua/osvita/zagalna-serednya-osvita/navchalni-programi/navchalni-programi-dlya-1011-klasiv (data zvernennia 26.01. 2021).

10. Himia [Chemistry]. Elektronnyj pidruchnyk: veb-sajt. URL: https://sites.google.com/view/allhemi/ (data zvernennya 25.12. 2020).

11. Yurchenko A. A. Virtualnyje laboratorii v uchebnoj fyzycheskoj srede [Virtual laboratories in the learning physical environment]. Informacijni tehnologiyi $v$ profesijnij diyalnosti. 2016. № 10. URL: http://repository.sspu.sumy.ua/handle/123456789/979 (data zvernennia 27.01. 2021).

12. Yurchenko A. O., Xvorostina Yu. V. Virtualna laboratoria yak skladova suchasnogo eksperymentu [Virtual laboratory as a component of modern experiment]. Naukovyj visnyk Uzhgorodskogo universytetu. Seria: «Pedagogika. Socialna robota». 2016. Vyp. 2 (39). S. 281-283. 